\title{
Pendidikan Spiritual Melalui Peribadatan Taize di GMIM Sion Tomohon
}

\author{
${ }^{1}$ Victor Johannes Bella, ${ }^{2}$ Markus Wibowo, ${ }^{3}$ Siguti A. Sianipar \\ Institut Agama Kristen Negeri Manado \\ 11victorjohanes88@gmail.com, 2wibowomarkus986@gmail.com, ${ }^{3}$ gutistein89@gmail.com
}

\begin{abstract}
Abstrak
Penelitian ini untuk mendeskripsikan dan mengkaji bagaimana proses peribadatan Taizé serta menemukan Nilai-nilai Pendidikan spiritual di jemaat GMIM Sion Tomohon Wilayah Tomohon Satu dengan menawarkan sebuah konsep Peribadatan Taizé. Penelitian ini menggunakan metode penelitian kualitatif dengan pendekatan studi kasus.Temuan penelitian yaitu: (1) proses peribadatan Taizé bersifat oikumenis yang diatur agar jemaat menikmati dan puncaknya pada penghayatan akan makna hidup dalam membangun relasi dengan Tuhan sang hening, (2) nilai-nilai Pendidikan spiritual hendaknya mengajarkan jemaat akan pola hidup berbahagia dalam relasi dengan Tuhan dan sesama, sederhana, murah hati dan tangguh dalam menghadapi hidup. Peneliti merekomendasikan agar gereja melaksanakan pengajaran mengenai spiritualitas melalui peribadatan Taizé, sehingga dapat memudahkan jemaat merefleksikan diri untuk kemudian menemukan kembali makna hidup dan menata kehidupan agar wujud nyata cinta kasih Kristus senantiasa nampak lewat tutur dan lakunya.
\end{abstract}

\section{Kata Kunci: Pendidikan Spiritual, Peribadatan Taizé}

\begin{abstract}
This research is to describe and examine how the Taizé worship process is and to find the values of spiritual education in the GMIM Sion Tomohon congregation, Tomohon Satu region by offering a concept of Taizé Worship. This study uses a qualitative research method with a case study approach. The findings of the study are: (1) the Taizé worship process is ecumenical which is arranged so that the congregation enjoys and culminates in the appreciation of the meaning of life in building a relationship with the silent God, (2) educational values Spiritualists should teach the congregation about the pattern of living a happy life in relation to God and others, simple, generous and tough in facing life. The researcher recommends that the church carry out teaching about spirituality through Taizé worship, so that it can make it easier for the congregation to reflect on themselves and then rediscover the meaning of life and organize life so that the real manifestation of Christ's love can always be seen through his speech and behavior.
\end{abstract}

Keywords: Spiritual Education, Taizé Worship 


\section{Pendahuluan}

Banyak orang berupaya mencari cara untuk menemukan rasa tenang dan terlepas dari situasi cemas. Gereja seharusnya menjadi wadah dalam memberi edukasi dan pencerahan untuk jemaatnya.

Persekutuan merupakan salah satu hal yang paling menonjol bagi kehidupan umat Kristen dimana umat berkumpul bermada bakti. Dewasa ini, gereja belum dapat memenuhi banyak orang merasakan kebosanan dalam ibadah yang terkesan monoton.

Dalam peribadatan Gereja Masehi Injili Minahasa (GMIM) jemaat Sion Tomohon mengenal beberapa model peribadatan sebagai upaya pembinaan bagi jemaatnya yakni peribadatan yang sifatnya Konvensional, Ekspresif dan Meditatif.

Peribadatan sifatnya meditatif jarang kita temui dalam lingkungan pelayanan Gereja Masehi Injili Minahasa yaitu Taizé,

ibadah ini bisa dikatakan sebagai peribadatan yang khusus karena merupakan peribadatan yang dilaksanakan pada peristiwa khusus.

\footnotetext{
${ }^{1}$ Sr. Angelica, P.Karm, St Teresa Avilla: Tahap-tahap Doa, Makalah VIII, 2004, hh 1-2

2 Mamik, Metodologi Kualitatif, (Sidoarjo: Zifatama Publishing, 2015), h. 83.
}

Ungkapan St Teresa Avilla bahwa Allah senang diam dalam hati orang yang tenang dalam segala keindahan, ${ }^{1}$ peribadatan Taizé di jemaat GMIM Sion Tomohon menambah kekayaan liturgi serta mampu memberi dampak positif dalam upaya Pendidikan spiritual.

Pengkajian secara mendalam terhadap Peribadatan Taizé, akan peneliti uraikan dalam tulisan ini dengan judul: Pendidikan Spiritual melalui Peribadatan Taizé di GMIM Sion Tomohon.

\section{Metode}

Dalam tulisan ini penulis menggunakan metode penelitian kualitatif bersifat deskriptif.

Penelitian ini dilakukan bulan april 2021 sampai agustus 2021, namun telah didahului dengan tahap pra observasi yang berlangsung pada bulan Desember 2020. Tempat penelitian GMIM Sion Tomohon

Instrumen penelitian adalah peneliti sendiri, dalam pemanfaatan manusia sebagai instrumen penelitian menggapai dan menilai makna dari suatu peristiwa atau berbagai interaksi sosial. ${ }^{2}$

Teknik pengambilan sampel menggunakan teknik Purposive Sampling dan teknik Snowball Sampling. ${ }^{3}$ Peneliti

\footnotetext{
${ }^{3}$ Sugiyono. Metode Penelitian Kuantitatif, Kualitatif, dan R \& D. Bandung: Alfa Beta, 2016.
} 
membutuhkan informan yang mengetahui secara jelas mengenai situasi dan kondisi.

Dalam penelitian ini, proses pengumpulan data dilakukan dengan teknik penelitian observasi, wawancara dan studi dokumen.

Observasi dalam kegiatan ibadah yaitu ibadah jemaat dan kegiatan bermusik dalam hal ini yang berkaitan dengan ibadah dengan nyanyian dari Taizé.

Wawancara dilakukan dengan wancara terstruktur dan wawancara tidak terstruktur atau wawancara mendalam. ${ }^{4}$ Peneliti mewawancarai informan yang terdiri dari, penyanyi atau kantoria, pendeta dan jemaat.

Penelitian studi dokumen dilaksanakan dengan cara pengumpulan data dan informasi berasal dari dokumendokumen berupa buku-buku, jurnal musik, teks-teks mengenai nyanyian meditatif, liturgi ibadah GMIM, serta berbagai literatur maupun referensi yang berkaitan dengan musik Taizé .

Tahap reduksi data dengan menggolongkan dan menganalisis data selanjutnya menyajikan atau memaparkan dan mengambil kesimpulan atau tindakan dalam penelitian sesuai dengan tujuan yang hendak dicapai.

${ }^{4}$ https://id.m.wikipedia.org/wiki/Wawancara

\section{Hasil dan Pembahasan}

a. Sejarah dan Perkembangan GMIM Sion Tomohon

Gereja "Sion" Tomohon, sebelumnya indische kerk (Gereja Protestan Hindia Belanda) Gereja Sion merupakan Sebuah bangunan gereja tipikal tanpa candi yang menjulang tinggi dan tanpa aksesoris berlebihan. Setelah ditahbiskan pemakaiannya dalam suatu upacara pada 23 Februari 1930, lalu disebut "Gereja Besar" (Gereja Basar) Protestan Tomohon.

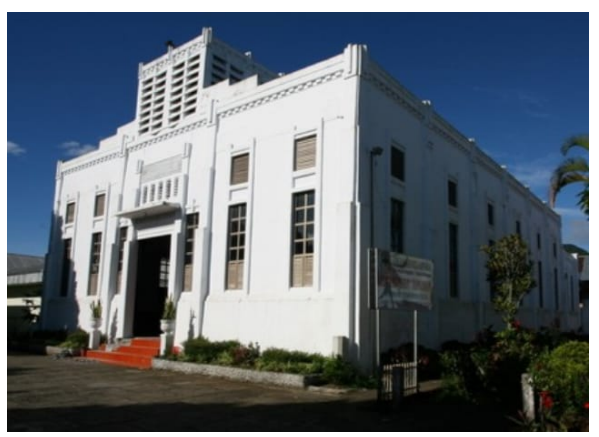

Gambar 1. Gereja GMIM Sion Tomohon (dokumentasi pribadi, 2021)

Kegiatan-Kegiatan Di Jemaat Sion Tomohon

Bentuk kegiatan yang ada di Jemaat Sion Tomohon meliputi Liturgi, Pewartaan, Kemasyarakatan, pendidikan, dan Persaudaraan, Sarana dan Prasarana, Penelitian dan Pengembangan. ${ }^{5}$ Setiap hari minggu dilaksanakan ibadah rutin di Gedung gereja secara streaming dan juga 
dihadiri oleh petugas ibadah dan beberapa anggota jemaat. Layanan doa buat jemaat seringkali hanya dilaksanakan lewat media video call saja atau melalui telepon. ${ }^{6}$

\section{b. Peribadatan Taizé di GMIM Sion Tomohon}

Ibadat Taizé diadakan pertama kalinya 20 februari 2020. Saat ini kegiatan Peribadatan dengan menggunakan nyanyian Taizé terus dilaksanakan dengan memasukan beberapa praktek ibadah Taizé memberi kesempatan bersaat hening unsur tertentu dan nyanyian Taizé sering juga dimunculkan dalam kegiatan ibadah minggu.

Peneliti menemukan Nilai-nilai Spiritualitas Taizé memberi inspirasi segar untuk kehidupan spiritualitas gereja. $^{7}$ Pendidikan spiritual lewat peribadatan menjadi bekal bagi segenap jemaat untuk menjalani hidup di tengah masyarakat dan arus dunia yang semakin kompleks.

Pendidikan spiritualitas menyangkut keseluruhan aspek kehidupan yang dimiliki orang Kristen. ${ }^{8}$ Spiritualitas merupakan sebuah hasil dari pertemuan antara manusia dengan Allah dan hasilnya

\footnotetext{
${ }^{6}$ Observasi peneliti 3 juni samai 6 juni 2021

7 Wancara kepada ketua BPMJ Sion Tomohon 30 juni 2021 pukul 15.20

${ }^{8}$ Dokumen Proposal Panitia Kegiatan Hari Raya Gereja tahun 2021
}

diwujud nyatakan melalui seluruh bidang/aspek kehidupan manusia tersebut.

\section{c. Proses Peribadatan Taizé Di} Jemaat GMIM Sion Tomohon.

GMIM Sion Tomohon selalu akrab dengan penataan ibadahnya dan merupakan hal yang biasa terjadi dalam setiap ada pertemuan ibadah mulai dari nyanyian pembuka, votum dan salam dan seterusnya sampai dengan pujian penutup atau yang biasa dikenal dengan istilah pujian pengutusan. ${ }^{9}$ Hal ini hendak memberi tanda bahwa ibadah yang keseluruhan penataan liturgi tidak terpisah antara satu dengan menarasikan cinta kasih Kristus pada dunia.

Sejak Ibadah Taizé pertama kali dilaksanakan telah mendapat respon yang baik dari anak muda dan lansia yang waktu itu mendominasi kehadiran dalam kegiatan tersebut dengan mengadakan persekutuan doa 15 februari 2020 diadakan di Gedung gereja Sion Tomohon. Untuk persekutuan doa gabungan dari masing-masing kolom diadakan pada malam hari. Petugas ibadahnya adalah pendeta dan frater-frater dari sekolah tinggi filsafat (seminary pineleng) sebagai petugas musik dan

\footnotetext{
${ }^{9}$ Obserwasi peneliti dalam kegiatan ibadah sewaktu terlibat pelayanan bersama Tim music peribadatan
} 
pengarah lagu bersama kantoria dari gmim Sion Tomohon.

Nilai oikumenis lewat Peribadatan memberi makna tersendiri dalam membangun keutuhan dan keselarasan dalam menata hubungan lintas tradisi dengan berorientasi pada satu tubuh dengan Kristus sebagai kepalanya. ${ }^{10}$

Proses demikianlah juga yang hendaknya memberi gambaran pada suatu nilai Kristosentris yang didalamnya merupakan cerminan komponen spiritualitas, yaitu kehidupan Kristus, ajaran Kristus dan firman Tuhan. ${ }^{11}$

Christy menuturkan: Tuhan menggunakan momen doa sebagai sarana untuk dia berbicara dan lewat momen tersebut kita diajar, dididik, dan ditegur.

Capaian peningkatan spiritualitas secara pribadi yang mempersiapkan hati dan pikiran jemaat menuju pemberitaan Firman Tuhan. Keutuhan nilai yang kita dapat dalam sebuah ibadah menawarkan modal bagi kita untuk semakin kokoh dalam menjalani hidup yang benar bersama Kristus.

Daniel pianis gereja Sion Tomohon mengutip pujangga Gereja Santo Augustinus dari Hippo "Qui bene cantat, bis orat " la yang bernyanyi

\footnotetext{
10 Ibu Jedida Santosa melalui akun facebook 15 februari 2021

11 Christy mangantare dalam wawancara 21 agustus 2021 pukul 15.15 WITA

12 Daniel dalam wawancara 7 maret 2021
} di Gedung gereja 11.17 WITA dengan baik sama dengan berdoa dua kali. ${ }^{12}$

Tempat yang sepi dan hening dipilih untuk merasakan perjumpaan dengan Allah lewat nyanyian dan doa.

Demikian juga dengan urutan dalam penataan ibadah sesuai dengan bagian litaninya masing-masing. ${ }^{13}$ Peningkatan spiritualitas jemaat sepadan dengan kaidah nilai litani yang sedang berlangsung mewujudkan cerminan Kristus yang melalui pola hidup, pola pikir dan pola tindakan secara individu maupun sosial.

Peningkatan spiritualitas menghantar jemaat untuk mengalami perjumpaan dengan Tuhan yang kemudian mempengaruhi pola hidup, pola pikir dan pola tindakan. Berpikir sebagaimana Kristus berpikir; bertindak sebagaimana Kristus bertindak; dan berkata-kata sebagaimana Kristus berkata.

Nyanyian Taizé dan Doa yang kuno telah menjadi pilihan dalam bentu peribadatan seperti ini dikarenakan teks yang di dalamnya memiliki spirit yang mempengaruhi jiwa dan laku seseorang. Jemaat juga berdoa sambil menaikan mazmur dan pujian. ${ }^{14}$

\footnotetext{
13 Wawancara dengan pendeta Azer Roeroe 30 juni 2021 pukul 08.40 di pastori

${ }_{14}$ Wawancara bersam Pdt. Azer Roeroe di kediamannya tanggal 29 juli 2021 pukul 09.50 WITA
} 
Praktek doa dan nyanyian dari Taizé di jemaat Sion Tomon memakai lagu-lagu hymns yang berasal dari Kidung Jemaat (KJ), Nyanyikanlah Nyanyian Baru Bagi Tuhan (NNBT), dan Pelengkap Kidung Jemaat (PKJ). Hal ini memudahkan Jemaat mendapatkan buku nyanyian tersebut dan juga bisa memilih nyanyian yang cocok dengan suasana kontemplasinya.

Doa yang diadakan seperti doa syafaat dengan juga menggabungkan ujud mendoakan umat yang terdampak virus covid-19 juga mendoakan arwah mereka yang telah meninggal karna virus ini. ${ }^{15}$ Terlepas dari ajarannya doa menjadi saluran rahmat bagi orang yang masih hidup dan juga yang telah berpulang.

Kehadiran Peribadatan semacam ini menegaskan sesungguhnya gereja yang berkembang di zaman ini telah menjadi gereja yang terbuka dan dimerdekakan dari sekat tradisi serta aturan. ${ }^{16}$ Keterbukaan dijumpai, dijiwai dan diterapkan bersama.

"Pendeta mengungkapkan selama ini kita terlalu terkungkung dengan pemahaman yang telah lama dalam ajaran calvinis dan tidak relevan lagi mengenai beribadah sementara kajian teologi yang baru mengenai beribadah sudah lebih mudah dijangkau kemudian tinjauan

\footnotetext{
${ }^{15}$ Dokumentasi peneliti dalam video akun Facebook 15 februari 2020

16 Dokumentasi akun facebook Jedida Santosa 15 februari 2020
}

landasan teologi sudah semakin berkembang".

Oleh karena itu kebebasan dan kemerdekaan semestinya tetaplah merupakan nilai yang diamalkan secara bertanggung jawab dan bukannya kebebasan tak berarah. Hal yang penting untuk selalu kita renungkan bahwa Allah senang dengan keteraturan dan Dia begitu bertanggung jawab dalam merawat seluruh ciptaan.

\section{d. Nilai-nilai Pendidikan spiritual dalam ibadah Taizé}

Kebiasaan menyanyikan nyanyian dari Taizé juga dapat kita temui dalam Peribadatan biasa yang dilaksanakan pada hari minggu, dan cara menyanyikannya masih tetap sama dengan yang dipraktekan dalam Peribadatan Taizé yaitu dengan menyanyikannya secara berulang. ${ }^{17}$ Nilai pendidikan semacam ini di kembangkan untuk memungkinkan jemaat mengingat akan makna hidup dalam bermenung dan praktek pengulangan dengan intensitas tertentu mengentar pada suatu kesakralan sehingga olehnya membentuk pola hidup sesuai dengan Spiritualitas yang diajarkan.

\footnotetext{
${ }^{17}$ Wawancara kepada Pdt. Azer Roeroe 30 juli 2021 pukul 10.15 WITA di Kantor BKUA Kota Tomohon
} 
Dalam pelaksanaannya, Peribadatan model seperti ini mendatangkan anggapan seperti diuraikan oleh Esther Gunawan dengan mengkritisi Taizé memiliki sifat mistik serta wujud dari spiritualitas postmodern karena lebih menekankan aspek sosialnya, serta bersifat pasca doktrinal yang kurang menghargai atau mengabaikan doktrin karena bentuknya yang interdenominasi. Selain itu, dia menyarankan untuk melalui proses "demitologisasi", dengan kata lain pemahaman yang diadopsi kembali menyesuaikan dengan doktrin gereja setempat. Sebagai contoh perayaan perjamuan kudus yang diadopsi komunitas Taizé mengikuti paham transsubstansiasi. ${ }^{18}$ Menurut penulis, ini tidak menjadi masalah karena ini tidak menjadi hal yang substansi karena kita sematamata tidak bisa membatasi kehadiran dan Rahmat Allah.

Peribadatan ini semata-mata tidak terbatas pada proses ibadah formalnya melainkan pada momen spiritual berdiam diri dalam menghadirkan suasana kontemplasi. $^{19}$ Yang terpenting yaitu nyaman saat berdoa. Boleh dikatakan

18 Esther Gunawan, Tinjauan terhadap Spiritualitas Taize dan Telaah atas Kemungkinan Mengadopsinya sebagai Pendorong bagi Spiritualitas Injili, Veritas 2013, Vol 14 No 1

${ }^{19}$ Wawancara kepada Michael 15 juni 2021 pukul 14.25 dan Christy 13 juli 2021 pukul 15.00 bahwa jemaat akan lebih suka dengan cara cara berdoa yang biasa. ${ }^{20}$ Jadi yang paling tidak, jemaat benar-benar menciptakan relasi yang intim dengan Tuhan.

\section{e. Hubungan dengan Tuhan dan sesama}

Momentum ini Gereja berupaya memberi kesadaran bagi kita yang penuh keterbatasan sebagai momen spiritual yang berdaya guna mengatasi kerapuhan. ${ }^{21}$ Sebagai mahluk yang rapu manusia perlu menghadirkan Tuhan dalam hidup namun kerap kali manusia tak lepas dari yang namanya dosa, terlepas dari semua itu upaya untuk menjalin relasi dengan Allah hendaknya tetap ada. Manusia hendaknya mengundang Roh Kudus hadir dalam hidupnya.

"Datanglah ya Roh Kudus yalahkan api cinta kasihMu

Datanglah ya Roh Kudus, Datanglah ya Roh Kudus". ${ }^{22}$

Nyanyian diatas mengajarkan bahwa dengan mengundang Allah lewat Roh Kudus adalah upaya manusia untuk menjalin hubungan kembali dengan Allah. Dengan demikian nilai Pendidikan yang

${ }^{20}$ Wawancara kepda Pmdi. Cinly (Kantoria jemaat Sion Tomohon) melalui via telepon 20 juli 2021 pukul 19.00

${ }^{21}$ Wawancara kepada pdt Azer Roeroe 30 juni 2021 pukul 13.15 dan Christy Mangantare pukul 16.05 WITA

${ }^{22}$ PKJ 304 (YAMUGER) 
dapat diambil yakni upaya membangun relasi dengan Allah sang hening sangat penting terlepas dari ketidak-layakkan manusia itu sendiri.

Manusia merupakan makhluk sosial dimana manusia berada dalam keterkaitan dengan orang lain. Sementara itu nilai yang dapat menjadi pembelajaran adalah bagaimana tata-cara hidup dalam bermasyarakat untuk sling melengkapi sehingga, seseorang dapat hidup, bertumbuh dan berkembang. Dan oleh karena itu pula, pola hidup yang dikembangkan seharusnya merupakan pengembangan spiritualitas yang didasarkan pada ajaran Alkitab. Kitab suci mengajarkan, "hokum kasih" (Matius 22:37-39). Mengasihi Allah dan mengasihi manusia hanya bisa terwujud ketika dia menghayati anugerah tersebut dengan kegembiraan dan sukacita.

"Nyanyian dalam Taizé membawa rasa damai gembira dan sukacita, sehingga ketika saya pertama kali mendengarnya merasa nyanyian ini cocok dengan jiwa saya setidaknya nyanyian yang dengan gembira tetapi juga meneduhkan tetap ada dalam rangkaian ibadah, begitulah ungkapan dari J.L."

Ciri kehidupan orang Kristen adalah senantiasa bersukacita seperti yang tersurat dalam dalam kitab suci Ibrani 12:2

${ }^{23}$ Wawancara kepada Christy Mangantare 28 juli 2021 pukul 16.05 WITA bahwa salib Kristus bukan membawa kita kepada dukacita duniawi tetapi kepada sukacita yang kekal.

Pendidikan yang hendak kita petik dari spiritualitas tersebut menghayati sukacita dan kegembiraan tersebut di ekspresikan dalam nyanyian. Sukacita yang muncul dari pengalaman iman kekal dan tidak akan lekang oleh waktu, meskipun seiring berjalanya waktu akan terjadi perubahan. Sesunggunya kegembiraan dan sukacita merupakan bagian penting dalam hubungan antara Allah dan manusia tetapi juga tetapi juga relasi antar manusia itu sendiri.

Membangun relasi bersama kristus menjadi salah satu kebutuhan pokok dalam spiritualitas kristiani karena lewat hal demikian kita dapat belajar untuk lebih siap menghadapi segala sesuatu dengan sukacita, dengan kita bersukacita menjalani hidup maka kita juga memiliki semangat dalam melayani Tuhan dan sesama, demikian tutur Christy.

Hidup yang bergembira dan bersukacita sesungguhnya berada pada sebuah kesederhanaan kasih dalam kedamaian. Kesempurnaan sukacita terangkum melalui persekutuan dengan Yesus Kristus karena dengan memberi diri mengantarkan kita pada sukacita yang paripurna. $^{23}$ 
Upaya Memaknai Hidup Dengan

Kemurahan Hati

Sikap murah hati seharusnya menjadi pegangan hidup dalam membangun suatu relasi yang baik, harmonis, penuh kedamaian dan tidak ego terhadap sesama. ${ }^{24}$

Hal ini membawa kita pada suatu pengertian tentang nilai pendidikan melalui sifat yang menggambarkan ketulusan hati untuk menerima segala bentuk kekurangan ataupun kelebihan orang lain.

Matius 18:22, “... Aku berkata kepadamu: Bukan sampai tujuh kali, melainkan sampai tujuh puluh kali tujuh kali." Tentunya ini mengajarkan kita untuk siap memaafkan dalam situasi maupun kondisi apapun. Murah hati menyelaraskan kita dengan kehidupan yang sesuai dengan ajaran Kristus.

momentum dimana kita harus berbagi dengan rela dan kemurahan hati. Dengan demikian sifat ego dan mementingkan keinginan pribadi hendaknya dihindari. Hal yang kemudian mengakibatkan pembunuhan karakter seharusnya tidak perlu dilakukan sebagai

\footnotetext{
${ }^{24}$ Wawancara bersama Christy 25 juli 2021 pukul 11.13 WITA di Gedung Gereja Sion Tomohon

${ }^{25}$ Wawancara bersama Vik. Pdt. Michael Aror 15 juni 2021 pukul 14.20 WITA

${ }^{26}$ Wawancara dengan Pnt. Wuena Pinaria lewat via telepon 20 juli 2021 pukul 19.50 WITA
}

contoh perkataan dan tindakan yang menyinggung atau melukai hati sesama kita. ${ }^{25}$

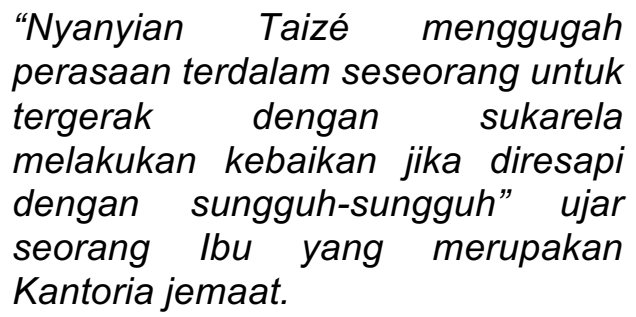
perasaan terdalam seseorang untuk tergerak dengan sukarela melakukan kebaikan jika diresapi dengan sungguh-sungguh" ujar seorang Ibu yang merupakan Kantoria jemaat.

Dengan menempatkan nilai kerendahan hati akan memungkinkan manusia itu sendiri untuk tergerak dengan sukarela menolong bagi orang yang membutuhkan pertolongan, mengalir ke mulut yang berdoa, menghibur, mengampuni dan saling menguatkan. ${ }^{26}$

\section{Menemukan Nilai Pendidikan Dalam} Spiritualitas Taizé Melalui Kesederhanaan Spiritualitas kesederhanaan mengajarkan tentang penghayatan hidup berkecukupan yang saat ini hendak dikembangkan oleh komunitas Gerejawi dengan mengambil landasan Matius 6:11 "Berikanlah kami pada hari ini makanan kami yang secukupnya" Kesederhanaan melawan sikap boros dan rumit.

Brother Roger mengajarkan nilai kesederhanaan sebagai untuk bertahan. ${ }^{27}$

27 Sihotang, Kajian Musik Liturgi Dalam Ibadah Persekutuan Doa Meditatif Kelompok Doa Nyanyian Taizé Di Sarasvita Faithful Companions Of Jesus (Fcj) Centre Yogyakarta (Institut Seni Indonesia Yogyakarta 2019), h. 14 
Seperti halnya dengan nyanyian Taizé yang sederhana memungkinkan orang mudah diingat sehingga anggota jemaat tidak lip-syncronisation saat beribadah.

Nyanyian Taizé mengajarkan kita tentang kebebasan dari kecemasan. $^{28}$ Dengan kesederhanaan kita juga akan dimampukan untuk memerangi kerumitan, karena kerumitan membuat orang terlalu memaksakan diri pada sesuatu yang sulit dijalani.

Hidup dalam hening yang dikembangkan di dalam Peribadatan Taizé, tidak semata-mata menjadi "fatamorgana" di antara sorga dan bumi. Dasar yang sering dipakai untuk keheningan di Taizé adalah dari Roma 8:26, “... tetapi Roh sendiri berdoa untuk kita kepada Allah dengan keluhan-keluhan yang tak terucapkan".

\section{Tangguh Dalam Menghadapi Persoalan}

Yesus mengajarkan mengambil waktu untuk hening dan bercakap-cakap dengan BapaNya (Lukas 4:42-44) dan kembali dengan misiNya di tengah dunia yang dikenal dengan istilah Spiritualitas Pergi-Pulang. ${ }^{29}$

${ }^{28}$ Taize song Nada de Turbe (Song of Taize, 1984)

${ }^{29}$ Nouwen, Henri J.M; Dalam nama Yesus: permenungan tentang kepemimpinan Kristiani /
Nilai Spiritualitas semacam ini nampak nyata dalam teladan Yesus melalui doa, persekutuan, dan keheningan. Hal ini tidak untuk mengajarkan pada manusia untuk meninggalkan atau melarikan diri dari kenyataan dunia ini, tapi hendak mengajarkan untuk berani hidup dengan penuh makna dan siap diutus ke tengah-tengah dunia ini.

"Tinggallah bersama aku di dalam doa, di dalam doa". 30

Spiritualitas pergi mengajarkan menarik diri dari keramaian untuk mencari keheningan dan menemukan Allah.

Selanjutnya pulang, mengajarkan kita untuk kembali pada kehidupan ramai untuk sarat akan kerumitan.

"Tuhanlah kekuatanku, Tuhanlah nyanyianku Dialah kes'lamatanku Jikalau Dia di pihakku, terhadap siapakah 'ku gentar". ${ }^{11}$

Peribadatan dengan yanyian Taizé mestinya dapat secara efektif menjadi sarana pendidikan spiritualitas pergipulang untuk lebih tangguh dalam menjalani hidup.

\section{Kesimpulan}

Dari berbagai uraian tentang ibadah Taizé di atas penulis dapat

\footnotetext{
diterjemahkan oleh I. Suharyo $\operatorname{Pr}$ (Yogyakarta: Kanisius, 1993)

30 Tata Ibadah Taize GMIM Sion tomohon tanggal 15 Februari 2021

${ }^{31}$ PKJ 307 (YAMUGER)
} 
menyimpulkan bahwa proses Peribadatan Taizé di Jemaat Sion Tomohon:

1. Masih menggunakan Ordo yang umumnya digunakan oleh Gereja Protestan bentuk oikumenis.

2. Ibadat dengan nyanyian Taizé dirancang sebaik mungkin agar jemaat yang terlibat menikmati peribadatan ini dengan prinsip Allah menyukai keteraturan.

3. Praktek hening dan nyanyian dibawa pada kegiatan ibadah minggu sehingga jemaat akan terbiasa dan kemudian menjadi gaya hidup membangun relasi dengan Allah.

Nilai-nilai Pendidikkan Spiritualitas melalui Peribadatan Taizé mengarah pada menghayati makna hidup yang berujung pada perubahan karakter maka nilai Pendidikan spiritualnya adalah:

1. Hubungan yaitu terjalinnya kembali hubungan antara manusia dengan Allah dan sesama dengan damai dan sukacita serta hidup dalam kegembiraan.

2. Murah hati memungkinkan manusia terhindar dari perselisihan yang akhirnya manusia menjadi renda hati dan saling menolong.

3. Kesederhanaan menjadikan manusia terjebak dalam kemewahan yang rumit sehingga manusia itu sendiri lebih tulus dan hidup apa adanya.
4. Tangguh dalam menghadapi persoalan dimana setiap tindakan yang akan dilakukan selalu dihalui dengan bercakap-cakap dengan Allah dalam keheningan.

\section{Kepustakaan}

Esther Gunawan, Tinjauan terhadap Spiritualitas Taize dan Telaah atas Kemungkinan Mengadopsinya sebagai Pendorong bagi Spiritualitas Injili, Veritas 2013, Vol 14 No 1

Mamik, Metodologi Kualitatif, Sidoarjo: Zifatama Publishing, 2015

Nouwen, Henri J.M; Dalam nama Yesus: permenungan kepemimpinan Kristiani / diterjemahkan oleh I. Suharyo Pr Yogyakarta: Kanisius, 1993

PKJ 304 (YAMUGER)

PKJ 307 (YAMUGER)

Sihotang, Kajian Musik Liturgi Dalam Ibadah Persekutuan Doa Meditatif Kelompok Doa Nyanyian Taizé Di Sarasvita Faithful Companions Of Jesus (Fcj) Centre Yogyakarta (Institut Seni Indonesia Yogyakarta 2019

Sr. Angelica, P. Karm, St Teresa Avilla: Tahap-tahap Doa, Makalah VIII, 2004

Sugiyono. Metode Penelitian Kuantitatif, Kualitatif, dan R \& D. Bandung: Alfa Beta, 2016

Taize song Nada de Turbe Song of Taize, 1984

Tata Ibadah Taize GMIM Sion tomohon 